\title{
Report on EUROPEAN CONSULTATION ON REFUGEES AND EXILES (ECRE) MEETING
}

\author{
September 22-23, 1990, Geneva, Switzerland
}

By Helga Kutz-Harder

The major concerns of ECRE participants this summer related to protecting the human rights of refugee claimants throughout Europe. Three areas of concern permeated the discussions: (i) access to fair determination procedures throughout Europe and the low success rate for most claims (5\% in many countries); (ii) longterm second class status for even successful refugee claimants; (iii) dangerous refoulment of refugees, notably, but not exclusively, to Sri Lanka. The failure of most European states to facilitate family reunification surfaced as a last minute business item; the brief intense discussion focused on hurt experienced by refugees as a result of long, enforced separations from their families the same kind that Canadians are documenting in the ICCR refugee backlog study.

The tone of the ECRE meetings recalled the frustration of refugee advocates in the many cross-Canada discussions before Bill C55 and C84 were turned into law. The participants were preoccupied with three refugee-related documents which have been signed but not yet ratified by Buropean countries:

1. A Convention on asylum signed in Dublin on June, 1990 without the participation of the European Parliament - this declaration deals with who is responsible for refugee determination;

2. A Convention on the crossing of external borders being discussed in Rome, which does not protect human rights standards and does not conform to international standards of data protection;

3. The Schengen agreement harmonizing refugee procedures in Prance, Netherlands, Germany, Belgium and Luxembourg.

Since all have yet to be ratified by the respective parliaments, the NGO community throughout Europe is involved in intense lobbying to change the agreements so that refugees and refugee rights will be protected.

Besides being critical of their content, ECRE participants were highly critical of the non-consultative and even secretive process in which these agreements were developed. The general impression was that they will, in effect, severely limit the numbers of African and Asian refugee/ asylum seekers/migrants who can seek protection in Europe. All of them reflect a blurring of the distinctiveness and purposes of refugee, immigration, and foreign policy. Consequently real refugees are being denied access to Europe or are being refouled to thetr country of origin. A long discuselion about how to respond to these defective conventions and declarations included the following familiar questions:

a. Is it better to work to have bad legislation thrownout altogether or work to change what already exists until it is good enough to live with? (Strong arguments on both sides with no consensus)

b. Can the new agreements be challenged in the Hague? (Feasibility is unclear)

c. Can the agreements be publicly condemned without offering an alternative policy? (ultimately they decided yes)

d. Can ECRE issue a public statement when member agencies have not had time to vet the statement with their constituencies and when a few participants did not agree with the statement? (ECRE issued a condennnation of the three agreements in the name of the ECRE meeting without mentioning dissenting voices, sirce the majority agreed.)

e. How doNGO'skeepup the fight in the face of governments who do what they want anyhow? (Collective indignation and strong collegiality)

The Swedish government has published a background paper in preparation for a future immigration policy which seems to be modelled on Canada's new policy and has the same defects. The otherScandtnavian countries are certain that their governments will follow suit. The Swiss government has published a similar background paper which is also being criticized by the NGOs.

The final rich discussion addressed root causes, taking a holistic approach to the refugee question, balancing aid and leadership development, analyzing the fundamental relationship between human rights violations and Third World debt and poverty and matural disasters and ethnic conflict, and suggesting paradigmshifts from control of the world by Europe and North America. The debate made this particular ECRE meeting a unique privilege for me.

A comment by a colleague from the Netherlands focused the response: If governments are at a loss about where the world is going we don't have to be."

ECRE spent some time looking at the nature of its organization and how that affects its policy making potential. At the moment BCRE has no constitution and continues to be a flexdble consortium of refugee-related agencies. While this causes consternation to governments who might wish to give BCRE delegate status in certain situations, the participants firmly decided to remain with this arrangement. Consequently, policy papere emanating from ECRE become suggestions for positions which member agencies may adapt, change, discand, or ratify as their own. Within this framework, the high degree of unanimity on the important questions of refugee protection was inspiring- 